\title{
Who Gets on Top in Democracy? Elections as Filters
}

\author{
Robert Cooter *
}

Economic models of politics usually assume that all politicians maximize their narrow self-interest, so the constitution and other laws should be designed to constrain the worst people. In contrast, I assume that different politicians have different traits of character, so the constitution and other laws should be designed to promote the best and demote the worst. Successful filtering of politicians partly determines whether a country enjoys good or bad government. In my model, each election serves as a filter, so, up to a point, more elections filter better. Countries that suffer bad government do so partly because politicians face too few elections for the citizens to identify the worst characters and remove them from office. These countries, however, should not necessarily shorten the term of office in order to have more frequent elections. Rather, these countries should reduce the depth of administration and create a federal structure with more elected governments. Similarly, these countries should tilt influence towards voters and away from party leaders by favoring winner-take-all elections.

"I agree with you that there is a natural aristocracy among men. The grounds of this are virtue and talent. .. . May we not even say that that form of government is the best which provides for a pure selection of these natural aristoi into the offices of government?"-Thomas Jefferson writing to John Adams. ${ }^{1}$

"Herman Selvin Professor of Law, University of California at Berkeley. Email rcooter@law.berkeley.edu

1 Thomas Jefferson, Letter of Oct. 28, 1813, in Thomas Jefferson, Writings 1305-06 (The Library of America, N.Y., 1984).

(C) 2003 by the University of Chicago. All rights reserved. 0-226-99962-9/2003/0010-0006\$10.00 
What kind of people gets on top in politics? Jefferson believed that democracy causes the best to rise to the top. Elections empower a "natural aristoi" of talent and virtue. Conversely, Hayek believed that socialism causes totalitarianism and totalitarianism causes the worst to rise to the top. (Chapter 10 of The Road to Serfdom bears the title, "Why the Worst Get On Top.") This paper goes beyond these suggestions and begins to model the connection between good character and good government.

In spite of its recent fluorescence, formal political theory remains silent about this problem. I have in mind theories variously called "rational-choice," "public choice," "collective choice," "positive political theory", and "mathematical politics." To illustrate, the widely used spatial model of electoral competition works like this. Each candidate for elected office chooses a platform represented by a point in the space of political issues, each citizen has a most-preferred point in the space, and each citizen votes for the candidate whose platform is closest to his most-preferred point. In spatial models, politicians are placeholders for platforms, not people with personality and character.

Economic models of politics, including but not limited to spatial models, tend to regard politicians as selfish maximizers of power. Following this approach, political theorists design political institutions for the worst people to hold office, much like Holmes designed laws to constrain the "bad man." ${ }^{2}$ Devices to constrain the worst politicians include separation of powers, checks and balances, rule of law, and competitive elections. Refining these devices is a great accomplishment of democratic theory. ${ }^{3}$

The political theory of constraints is essential but incomplete. Even the best legal and political constraints are so imperfect that officials inevitably enjoy much discretionary power. Given discretionary power, better character of officials makes for better government. Voters apparently recognize this fact because, contrary to spatial models, personalities often dominate issues in real elections. Voters strain to discern the characteristics of candidates and decide who can be trusted with power. A complete theory must take seriously differences in politicians' character. Whether a country enjoys good government or suffers tyranny and kleptocracy depends on how its laws and institutions select and constrain politicians.

I will apply economic models of filtering and signaling to politics. Specifically, I analyze elections as filters that retain some types of people and discard others. Instead of regarding politicians as equally selfish and differently constrained, I regard the legal and political in-

\footnotetext{
${ }^{2}$ For a recent symposium on Holmes's theory, see Boston University Law Review, volume 78 (1998).

${ }^{3}$ I review these accomplishments in Robert Cooter, The Strategic Constitution (Princeton U Press, 2000).
} 
stitutions that supply the constraints as filtering politicians for their personal attributes.

In a previous paper I argued that too few elections can cause corruption, and this fact explains much corruption in developing countries. ${ }^{4}$ Similarly, I will argue here that too few elections insufficiently filter politicians. Countries that suffer bad government do so partly because politicians do not face enough elections for the citizens to identify the worst characters. Contrary to the populist tradition, however, I argue that these countries should not necessarily shorten the term of office in order to have more frequent elections. Rather, these countries should reduce the depth of administration and create a federal structure with more elected governments.

Part I relates the concept of preferences in economics to character in politics. ${ }^{5}$ Part II relates political filtering to the problem of the optimal number of elections. ${ }^{6}$ Part III concludes.

\section{PREFERENCES AND CHARACTER}

For economists, preferences are internal values manifested by choices, and opportunities are external possibilities bounded by constraints. Thus preferences belong to the person and opportunities belong to his world. Economics explains behavior as the collision of preferences and opportunities. In this section I will relate preferences to character. Later I will relate character to political opportunities.

\section{A. Self-Interest and Self-Expression}

Much of economic analysis proceeds by assuming that actors pursue their narrow self-interest. For example, businessmen pursue wealth, politicians pursue power, lovers pursue pleasure, and everyone pursues social prestige. ${ }^{7}$ Narrow self-interest encompasses wealth, power, pleasure, prestige, and little else. Just as economic theory encompasses different consumers with different preferences over goods, so eco-

\footnotetext{
${ }^{4}$ Robert Cooter, The Optimal Number of Governments for Economic Development, American Law and Economics Association, Annual Meeting, New Haven, May 1999; Conference on Market Augmenting Government, Institutional Reform and the Informal Sector (IRIS), Cosmos Club, Washington, DC, 26 March 1999.

${ }^{5}$ This section draws on Robert Cooter and Melvin Eisenberg, Fairness, Character, and Efficiency in Firms, 149 U Pa L Rev 1717 (2001).

${ }^{6}$ This is the title of Part II of Cooter, Strategic Constitution (cited in note 3 ).

${ }^{7}$ In most investment models, investors only different in their attitudes towards risk that they apply to the pursuit of wealth. In most models of political competition, politicians only seek to win elections. For more recent theories concerning prestige, see Richard H. McAdams, Cooperation and Conflict: The Economics of Group Status Production and Race Discrimination, 108 Harv L Rev (1995). For a hedonistic model of sex, see Richard Posner, Sex and Reason (Harvard U Press, 1992).
} 
nomic theory can encompass different actors with different values. From a formal viewpoint, the actors in economic theory, instead of being narrowly selfish, can value truthfulness, integrity, prudence, generosity, kindness, beauty, and so forth.

Broadening and softening motivation seems necessary to explain how people actually behave in some circumstances, including political behavior. Three examples follow.

First, narrowly self-interested citizens with ordinary attitudes towards risk would not pay taxes at the rate that they do in the U.S. or Switzerland. ${ }^{8}$ The possibility and severity of punishment is too low for deterrence to explain observed rates of tax compliance in these countries.

Second, narrowly self-interested voters would not participate in general elections at observed rates. ${ }^{9}$ Participation rates must fall far below current levels before the selfish payoff expected from casting a vote equals the opportunity cost of the time spent voting.

Third, judges must recuse themselves from cases that implicate their narrow self-interest. Judges obey this legal obligation in countries that enjoy the rule of law. Consequently, narrow self-interest provides little basis for independent judges to decide cases. ${ }^{10}$

The theory that all behavior is narrowly self-interested also contradicts experiments. In laboratory games conducted by economists and social psychologists, people persistently cooperate more than predicted by the assumption that they are narrow interested. For example, people share payoffs with others when anonymity assures that doing so is unnecessary. ${ }^{11}$

With narrow preferences, most acts are instrumental. For example,

${ }^{8} \mathrm{~W}$. Pommerehne and Bruno S. Frey, The Effects of Tax Administration on Tax Morale (unpublished manuscript 1992).

${ }^{9}$ Richard L. Hasen, Voting Without Law?, 144 U Pa L Rev 2135.2179 (1996); T. R. Palfrey and Howard Rosenthal, Voter Participation and Strategic Uncertainty, 79 Am Pol Sci Rev 62 (1985).

${ }^{10}$ Econometric studies of judicial motivation find little or no narrowly selfinterested basis for the behavior of federal judges in the US. For attempts to find such a basis, see Gary M. Anderson, William F. Shughart II, and Robert D. Tollison, On the Incentives of Judges to Enforce Legislative Wealth Transfers 32 J L \& Econ 215 (1989); Jonathan Macey, Transaction Costs and the Normative Elements of the Public Choice Model: An Application to Constitutional Theory, 74 Va L Rev 471 (1988); Richard S. Higgins \& Paul H. Rubin, Judicial Discretion, 9 J Legal Stud 129, 137 (1980). The behavior of state judges subject to partisan elections, however, can be explained in part by the need to deliver economic benefits to voters in order to win elections. See Eric Helland and Alex Tabarrok, The Effect of Electoral Institutions on Tort Awards, Berkeley Law and Economics Workshop (2001).

${ }^{11}$ See Max H. Bazerman and Margaret A. Neale, The Role of Fairness Considerations and Relationships in a Judgmental Perspective of Negotiation, in Kenneth J. Arrow et al., eds, Barriers to Conflict Resolution 86 (1995); Karen Cook \& Karen Hegtvedt, 
politicians kiss babies before cameras to gain votes. Conversely, as preferences broaden, more acts become ends in themselves. Bruno Frey has investigated empirically a variety of acts by citizens whose explanation apparently depends on "intrinsic motivation," by which he means virtuous acts done mostly for their own sake. He shows that treating people as public-spirited citizens evokes their intrinsic motivation, whereas bargaining with them crowds out intrinsic motivation. ${ }^{12}$

A person usually identifies intimately with his most important values, which form part of his self-conception. Acting from intrinsic motivation, consequently, expresses a person's identity.

Self-expression differs from self-interest. To illustrate, a person who thinks of himself as a good lawyer identifies with professional excellence in law. For such a lawyer, working on a case involves expressing himself, as well as making money. Weber and Durkheim recognized that identifying with occupational roles helps to solve the agency problems created by the complex division of labor in modern societies. ${ }^{13}$

I have contrasted narrow self-interest, such as making money, and self-expression, such as acting as a good lawyer. I have also discussed evidence that self-expression sometimes over-rides narrow self-interest in controlling behavior, as when a lawyer sacrifices fees in order to do what is best for his client. My belief, which I will not try to defend here, is that self-expression pervades behavior because most people cannot make a satisfactory identity from narrowly self-interested goals alone.

Self-expression differs from self-interest as narrowly defined, but is self-expression the same as self-interest broadly defined? In other words, does a deep analysis show that most self-expression is self-

Empirical Evidence of the Sense of fustice, in Roger D. Master \& Margaret Gruter eds. The Sense of Justice: Biological Foundations of Law 187, 197-200 (1992); Elizabeth Hoffman et al., Behavioral Foundations of Reciprocity: Experimental Economics and Evolutionary Psychology, 36 Econ. Inquiry 335, 347 (1998); Elizabeth Hoffman et al., Preferences, Property Rights and Anonymity in Bargaining Games, 7 Games \& Econ Behav 346, 371-72 (1994); Elizabeth Hoffman \& Matthew L. Spitzer, Entitlements, Rights, and Fairness: An Experimental Examination of Subjects' Concepts of Distributive Iustice, 14 J Leg Stud 259, 259-260 (1985); Matthew Rabin, Incorporating Fairness into Game Theory and Economics, 83 Am Econ Rev 1281, 1283 (1993); Paul Graham Loomes Burrows, The Impact of Fairness on Bargaining Behavior, presented at EALE annual meeting, Rome (1990).

${ }^{12}$ Bruno S. Frey, A Constitution for Knaves Crowds Out Civic Virtues, 107 Econ J 1043 (1997); Bruno S. Frey, The Cost of Price Incentives: An Empirical Analysis of Motivation Crowding-out, 87 Am Econ Rev 746 (1997).

${ }^{13}$ Max Weber, The Protestant Ethic and the Spirit of Capitalism (Charles Scribner's Sons, 1958); Emile Durkheim, The Division of Labor in Society (Free Press, 1984). 
interested? I will not address this question, which has no bearing on this paper. ${ }^{14}$

\section{B. Representing Intrinsic Motivation}

An internalized norm has two expressions. First, an actor may adhere to an internalized norm deliberately. By "deliberately," I mean from intentional commitment. Second an actor may adhere to an internalized norm reflexively. ${ }^{15}$ By "reflexively," I mean habitually or automatically. Deliberation is one source of reflexive commitment and socialization is another.

In either case, commitment to a norm receives weight in acting that can counterbalance the actor's narrow self-interest. To illustrate, assume that an actor recognizes that adhering to a norm has more costs than benefits as measured by his own power, wealth, or prestige. If he adheres to the norm anyway, then his adherence demonstrates commitment that outweighs narrow self-interest.

This fact suggests how to represent intrinsic values by standard economic methods. To express an internalized value, an actor sometimes makes a sacrifice of money, power, prestige, or pleasure. The sacrifice is the price of self-expression. "Willingness to pay" refers to the maximum amount that a person will pay for something. Figure 1 depicts "willingness to pay for self-expression."16 The vertical axis represents the price of self-expression as measured in terms of a scalable value such as money, power, prestige, or pleasure. The horizontal axis represents the proportion of people in the population who are willing to pay the price. ${ }^{17}$ Notice that a small proportion of people are willing to pay a lot to express the value in question, and a large proportion are willing to pay a little. More precisely, $80 \%$ are willing to

${ }^{14}$ I regard as vitally important the question of whether or not explaining political behavior requires a narrow or broad conception of individual values. But I regard the question of whether or not all behavior is ultimately selfish, including the pursuit of moral values, as a problem in philosophy that is largely irrelevant to social science.

${ }^{15}$ The economist Kaushik Basu describes reflexive adherence to a norm:

[Certain norms stop] us from doing certain things or choosing certain options, irrespective of how much utility that thing or option gives us. Thus most individuals would not consider picking another person's wallet in a crowded bus. This they would do not by speculating about the amount the wallet is likely to contain, the chances of getting caught, the severity of the law and so on, but because they consider stealing wallets as something that is simply not done.

Kaushik Basu, Social Norms and the Law, 3 New Palgrave Encyclopedia of Law and Economics 476, 477 (1998).

${ }^{16}$ We could also call the curve in Figure 1 the "intrinsically motivated demand curve."

17 Strictly, a cumulative density function. 


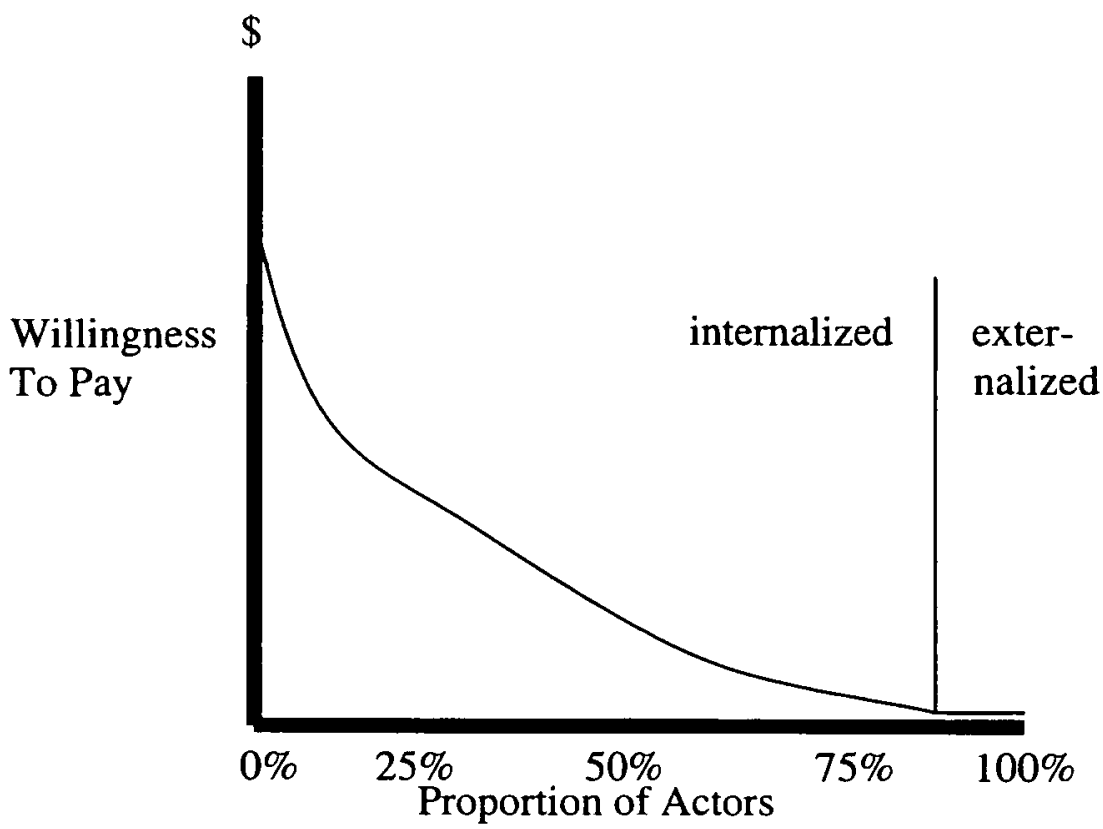

Figure 1. Willing-to-pay for expressive act.

sacrifice some self-interest to express the value in question, and $20 \%$ have not internalized the value and are unwilling to pay anything.

Economic theory distinguishes between "derived demand," which is needed for production, and "final demand," which is consumed. To illustrate, farmers hire labor (derived) to grow crops and households buy food to eat (final). Figure 1 represents an extension of the concept of final demand, which is intrinsic rather than instrumental.

In practice, the demand for some goods is mixed in the sense of being partly derived and partly final. To illustrate, a person buys a car for pleasure (final) and commuting (derived). Econometricians must separate the two aspects of demand in order to predict how demand will change in the future. To illustrate, relocating a factory typically changes derived demand for cars much more than final demand.

In standard economics, "tastes" are enduring dispositions with respect to goods. Enduring dispositions with respect to intrinsic motivation constitute "character." "Good" character usually means internalizing normative standards, which form an authentic disposition to adhere to the norms. To have good character, a person need not always adhere to norms. It suffices that he has the disposition to do so and typically does so. Demand curves such as Figure 1 formally represent the distribution of character in a population. 


\section{ELECTIONS AS FILTERS}

Are politicians narrowly self-interested or intrinsically motivated? According to Frank Knight,

[T] he probability of the people in power being individuals who would dislike the possession and exercise of power is on a level with the probability that an extremely tender-hearted person would get the job of whipping-master in a slave plantation. ${ }^{18}$

Successful politicians inevitably seek power, but an ambitious person can also be loyal or disloyal, truthful or dishonest, or cautious or reckless. While I assume that all successful politicians want power, I also assume that they differ in intrinsic motivation and self-constraint. Instead of thinking of everyone as narrowly self-interested, I assume that some politicians have intrinsic motives and normative standards. Given a distribution of character in the population of potential politicians, I ask how elections filter character.

\section{A. Good Political Character}

When recruiting and promoting members, different organizations filter for different traits. For example, the Mafia wants members who are strictly loyal to each other and ruthless towards outsiders. Thus the type of person who is good for an organization can be bad relative to the general norms of society. In contrast, the Catholic Church presumably prefers priests who treat everyone morally. A Mafiosi would make a bad priest, and vice versa. Thus the type of person who is good for one organization can be bad for another.

"Good organizational character" refers to the kind of character that makes an organization flourish. ${ }^{19}$ I use the term "good political character" to refer to the traits of an official that makes the polity flourish. Machiavelli became notorious for observing that good political character often contradicts good moral character. This paper, however, does not directly concern the question of what constitutes good political character. Instead, this paper concerns how elections filter for political character.

\section{B. Translucent Character}

Can voters discern the traits of politicians? To answer this question, I first discuss the general capacity of people to detect character. Since

${ }^{18}$ Frank H. Knight, J. Political Economy, December, 1938, p. 869 as cited by Hayek, Why the Worst Get on Top, in The Road to Serfdom 152 (Phoenix Books, University of Chicago Press, 1944) (penultimate paragraph in chapter X).

19 This concept is developed in Cooter and Eisenberg, Fairness (cited in note 5). 
cooperation among people often requires trust, people who can detect good character in others enjoy a competitive advantage in cooperative ventures. Evolution has, consequently, fitted us to detect good character in others. Similarly, people who can dissemble good character have an advantage in cooperative ventures. Nature has, consequently, fitted us to dissemble good character as well as to detect it.

Nature generally creates a parasite for every host. The very existence of a parasite, however, presupposes the host's existence. The possibility of deceit implies that people infer authentic character with less error than chance would produce. Otherwise, rational people would not attempt to make such inferences about character and no one could deceive anyone. I summarize these facts by saying that character is translucent, which means that people imperfectly see through actions into character. In statistical terms, translucence means that people correctly infer authentic character from behavior with higher frequency than chance would produce.

Psychologists have studied traits for some years. Some psychologists believe that people overestimate the stability of personality. This bias allegedly makes people mistakenly attribute behavior to fixed traits that actually depends on the particular situation. Other psychologists believe that statistical methods can greatly improve on the familiar terms used to characterize personality. According to this view, people have stable traits but not the ones that we think they have. ${ }^{20} \mathrm{I}$ will not discuss these disputes, which bear indirectly on this paper.

How do people detect traits of character in others? Figure 1 suggests an answer based on an analogy to the usual methods of preference revelation for consumer goods. People reveal how much they are willing to pay for a good when markets present them with prices. Similarly, people reveal the extent of their commitment to intrinsic values when confronted with tradeoffs demanding a sacrifice of narrow self-interest.

When people gain an advantaged from being perceived as having good character, they have an incentive to dissemble. The theory of market signaling suggests a way that people distinguish authentic from dissembled character. Different types of people, according to this theory, signal who they are by engaging in activities with a cost advantage for people of their own type. ${ }^{21}$ To illustrate, people signal that they are intelligent by obtaining an advanced college degree such as

${ }^{20}$ The factor analysis approach by Raymond Cattell especially pursued this goal. (A useful overview and bibliography is found at http://www.indiana.edu/ intell/rcat. tell.html.) More recently, psychologists have come to believe in the "big five" traits; see O. P. John, Chapter 3: The 'Big Five' Factor Taxonomy: Dimensions of Personality in the Natural Language and in Questionnaires in L. A. Pervin, Handbook of Personality: Theory and Research 66 (Guilford Press, 1990).

${ }^{21}$ The original work on signaling is Michael Spence, Market Signalling: Informa tional Transfer in Hiring and Related Screening Processes (Harvard U Press, 1974). 
the Ph.D. A more gifted student needs fewer years to finish the Ph.D. than a less gifted student does. In general, more intelligent people use up fewer resources than less intelligent people in getting a Ph.D. This fact makes dissembling intelligence by getting a Ph.D. very costly for unintelligent people. Similarly, active membership in a church can signal religious faith because participation in religious observance is easier for people who have faith than for people who lack it.

An activity is a pure signal if it provides information about the actor's traits without changing them. To illustrate, a Ph.D. is a pure signal of intelligence if people with Ph.D.'s are more intelligent on average than people without them, and if getting a Ph.D. does not make a person more intelligent.

Through repeated interactions, people transmit many signals whose accumulation increases the accuracy with which one person sees another. In general, successful filtering for character involves repetition. To illustrate, deceiving a stranger about yourself is easier than deceiving your teacher, and deceiving your teacher is easier than deceiving your mother.

Besides signals about ourselves, people like to talk about others and general beliefs in a community about a person's character constitute his reputation. Politicians acquire reputations through repeated exposure to citizens and lots of talk, even when few voters know the political candidates personally. People have complex motives for reporting on others that often lead to distortions and exaggerations. Filtering distortions and exaggerations out of information about others is an essential social skill. Besides repetition, successful perception of character involves filtering information about reputation.

\section{Hierarchies, Elections, and the Optimal Number of Governments}

An automobile manufacturer can make tires for its cars in a subsidiary or buy tires from another firm. Making tires involves one firm using hierarchical organization, whereas buying tires involves two firms transacting in a market. According to the standard formulation, firms are hierarchies bounded by markets. ${ }^{22}$ Hierarchies work by orders, whereas markets work by bargains. At the point where an organization touches a market, administration ends and trade begins. Vertical integration subtracts markets and vertical disintegration adds

22 Ronald Coase, The Nature of the Firm, 4 Economica 386 (1937); Oliver E. Williamson, Markets and Hierarchies, Analysis and Antitrust Implications: A Study in the Economics of Internal Organization (Free Press, 1975); Oliver E. Williamson, The Economic Institutions of Capitalism: Firms, Markets, Relational Contracting (Free Press 1985). 
markets. Along the vertical dimension, the extent of hierarchy and the number of markets measure the same thing with different sign. Optimizing the extent of hierarchy is, consequently, the same as optimizing the number of markets.

Turning from the private sector to the public sector, the ministry of education can administer local schools or the citizens in each locality can elect a school board for schools. The ministry of education is one organization and each school board is a small government. In this example, administration involves one hierarchical organization and politics involves many governments. Just as the private sector consists of hierarchies and markets, so the public sector consists of hierarchies and governments. Orders direct hierarchies and elections direct democratic governments. At the point where a public organization touches an election, administration ends and politics begins. Vertical integration subtracts elections and vertical disintegration adds elections. Along the vertical dimension, the extent of hierarchy and the number of elections measure the same thing with different sign. Optimizing the extent of hierarchy is, consequently, the same as optimizing the number of elections vertically.

My analogy between the firm and the state has focused on vertical integration or disintegration. Now I turn from vertical to horizontal organization. One firm can manufacture cars and another firm can grow cucumbers, or a single firm can do both. Horizontal merger reduces the number of firms and brings the allocation of capital under orders. In contrast, horizontal divestiture increases the number of firms and brings the allocation of capital under markets. Along the horizontal dimension, the extent of conglomeration and the number of markets measure the same thing with different sign.

Similarly, the scope of a government's power can encompass many issues or few issues. To illustrate, an elected town council can control police and a separately elected school board can control schools, or the town council can control both police and schools. The town council and the school board are the same level of government. Their relationship to each other is horizontal, not vertical as with the central government and a state government. When one democratic gov. ernment controls many issues, the citizens vote for one set of officials. When a separate democratic government controls each issue, the citizens vote for many sets of officials. In a democracy, the citizens vote for as many sets of officials as there are governments. Horizontal integration subtracts elections and horizontal disintegration adds elections. Along the horizontal dimension, the scope of government and the number of elections measure the same thing with different sign. Optimizing the scope of government is, consequently, the same as optimizing the number of elections horizontally. 


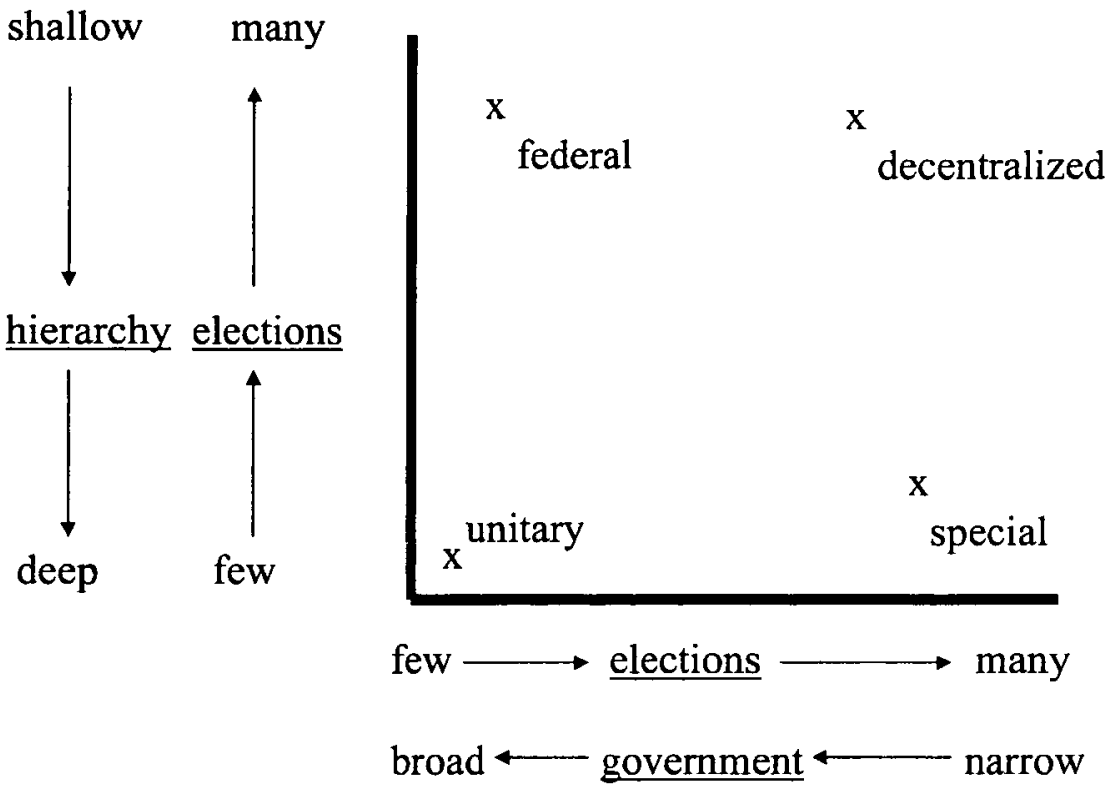

Figure 2. Organizational space.

Figure 2 depicts organizational space with the vertical dimension representing the depth of hierarchy and the horizontal dimension representing the breadth..$^{23}$ Equivalently, a point in the organization space of Figure 2 specifies the number of elections on the vertical and horizontal dimensions.

Different points in the organization space of Figure 2 correspond roughly to countries with different political subdivisions. Deep hierarchy and broad government, as indicated by the origin of the graph, characterize unitary states like Japan or France. Moving vertically from the origin holds the breadth of government constant while hierarchy becomes shallow. This move roughly depicts the change from a unitary state to a federal system like Canada or Australia, where the states have broad powers subordinated in some respects to the federal government.

Moving horizontally from the origin holds the depth of hierarchy constant while governments narrow. This move depicts the multiplication of special governments with single purposes. To illustrate, in the San Francisco area special district governments with separate

${ }^{23}$ While the feasible points are probably discrete (you cannot hold half of an election), the space is continuous. 
elections provide regional parks, public transportation, water, and other local public goods.

Finally, moving diagonally from the origin, governments narrow and hierarchies become relatively shallow. This move depicts the simultaneous decentralization and fragmentation of government.

Elsewhere I have argued that decreasing the breadth of government on the horizontal dimension can increase stability. ${ }^{24}$ Stability increases because diminishing the dimensions of choice reduces the probability that majority rule will cycle. Reducing the probability of cyclical majorities reduces the reliance on party structure to stabilize democratic politics. States plagued by instability should consider increasing the number of governments by narrowing the issues that they control.

Now I want to argue that decreasing the height of government on the vertical dimension will tend to improve the character of elected officials. Because character is translucent, observers can discern character better by repeated viewing of a person's behavior. Electoral campaigns test politicians by exposing them to repeated viewing by voters. A federal system usually forms a hierarchy of offices with a natural progression to power. In the U.S., for example, the progression goes, say, from city mayor to state governor to U.S. senator. Each stage in the progression gives voters another chance to scrutinize the candidate from a different viewpoint. Multiple observations from different viewpoints expose the politician's character more fully and filter better. A move towards federalism and away from the unitary state should tend to give citizens more of the information needed to gauge the traits of elected officials.

\section{Campaigns, Bargains, and Orders: The Optimal Number of Branches}

Convention distinguishes the branches of government into the executive, legislature, and judiciary. Discovering the best principles for dividing power among the branches of government has engaged the best minds in political theory. Their findings have contributed to the spread of stable democracies and the rule of law. Here I consider how the division of powers between executive and legislature affects filtering for character.

Competitive pressures operate differently in the different branches of government. In a pure presidential system like the U.S., the legislature and executive are separated, and citizens directly elect the chief

${ }^{24}$ Cooter, Optimal Number (cited in note 4). 
executive. When different political parties control the legislature and executive, party structure reinforces the constitutional separation of powers. When the same political party controls the legislature and executive, party structure undermines the separation of powers in direct proportion to party discipline.

In a pure Parliamentary system like the U.K., in contrast, the legislature and executive are joined. The citizens elect the legislature who elects the executive. Replacing the direct election of the executive as in a presidential system with indirect election as in a parliamentary system affects electoral campaigns. The party leaders, who hold safe seats and face weak electoral competition, do not have to campaign for their seats, but they must campaign for their party.

Combining a Parliamentary system with proportional representation further shifts the focus of competition from persons to parties. By definition, proportional representation divides seats in the legislature according to the proportion of votes that each party received. A party's leadership usually determines directly or indirectly the people who received the seats assigned to the party through the election. Control by party leadership operates directly when voters must vote for parties, not people. Control by party leadership operates indirectly when voters vote for people and the leaders determine who gets to stand for office in which district.

In any case, successful parties in a Parliamentary system usually require strong party discipline. Strong discipline is required because a party cannot participate in the governing coalition unless it can deliver the votes of its members. Government by coalition often prevails because proportional representation tends to prevent one party from obtaining a majority.

I have explained that Parliamentary systems with proportional representation, as opposed to presidential systems with winner-takeall elections, tilt the essential qualities of political success towards bargaining rather than campaigning. In other words, party leaders gain some control, and voters lose some control, over the careers of politicians.

Here I propose a connection between constitutional or party structure and the character of politicians. Electoral campaigns expose politicians to the scrutiny of voters. In contrast, political bargaining is relatively opaque to voters and gives fewer cues about the traits of politicians. So campaigning in elections allows citizens to filter politicians for character better than orders in administration or bargains in coalitions. For this reason, voters can filter politicians better for character in a federal system with winner-take-all elections than in a unitary system with proportional representation.

There is an argument in the other direction that must be rejected. 
Political elites, who know each other from long association, generally have better information than voters about the character of politicians. The leadership of parties can use this information to filter for character when making promotions. Political elites, however, have an interest in their own perpetuation that causes them to favor followers who are loyal. In contrast, voters, as noted early in this paper, often vote expressively, which allows scope for some altruism and regard for the public interest. Democratic theory is committed to the view that voters must control professional politicians. For this reason, filtering for character must operate through elections.

\section{C O N C L US I O N}

Economic theories of politics try to improve the behavior of politicians by improving legal and institutional constraints. The aim in designing laws and institutions is to align the politician's narrow selfinterest and nation's welfare, so that self-interested politicians serve the public good inadvertently. Instead, this paper considers how to select politicians for office with better character.

Here is a prescription to win a war: "Promote officers who win battles and demote officers who lose battles." Implementing this prescription requires fighting many battles and knowing the officers in charge. I apply this prescription to filtering for character in politics. In general, successful filtering for different types of people requires tracking their performance through many tests. Elections filter by repetition and reputation. Repeated elections over a politician's career and transparent electoral processes can provide voters with sufficient information to eliminate the worst characters from political office.

Countries that suffer bad government do so partly because politicians face too few elections for the citizens to identify the worst characters and remove them from office. These countries, however, should not necessarily shorten the term of office in order to have more frequent elections. Rather, these countries should reduce the depth of administration and create a federal structure with more elected governments. Similarly, these countries should tilt influence towards voters and away from party leaders by favoring winner-take-all elections. A federal system and winner-take-all elections improve the filtering of politicians, whereas a unitary system and proportional representation undermines it. 
HeinOnline -- 10 Sup. Ct. Econ. Rev. 1422003 